\title{
Magnesium: Effect on ocular health as a calcium channel antagonist
}

\author{
Magnezyum: Kalsiyum kanal antagonisti olarak göz sağlı̆ı̆ üzerindeki etkileri
}

\author{
Şafak Korkmaz ${ }^{1}$, Feyzahan Ekici², Hasan Ali Tufan ${ }^{3}$, Bahri Aydın ${ }^{4}$
}

\begin{abstract}
Magnesium is the physiologic calcium channel blocker, involving in many different metabolic processes by maintaining cell membrane function, modulating smooth muscle contraction and influencing enzymatic activities. Magnesium has been shown to increase blood flow to tissues by modifying endothelial function via endothelin-1 (ET-1) and nitric Oxide (NO) pathways. Magnesium also exhibits neuroprotective role by blocking N-methyl-D-aspartate (NMDA) receptor related calcium influx and by inhibiting the release of glutamate, hence protects the cell against oxidative stress and apoptosis. Both increase in blood flow and its neuroprotective effect make magnesium a good candidate for glaucoma studies. Magnesium has been shown to decrease oxidative stress and apoptosis in retinal tissue and to have retinal ganglion cell sparing effect. A series of studies has been conducted about magnesium could decrease insulin resistance in diabetic patients, ease glycemia control and prevent diabetic retinopathy. Magnesium is found to be critically important in maintaining normal ionic homeostasis of lens. Magnesium deficiency has been shown to cause increased lenticular oxidative stress and ionic imbalance in the lens so trigger cataractogenesis. J Clin Exp Invest 2013; 4 (2): 244-251
\end{abstract}

Key words: Magnesium, calcium channel blockage, glaucoma, neuroprotection, diabetic retinopathy, cataract

\section{INTRODUCTION}

Magnesium is an essential trace element for human life, and is also the second most common cation in the intracellular space. It plays a key role to function for many enzymes as a cofactor, including kinases. Magnesium is related to the stability of cell walls, and many magnesium containing enzymes are involved in metabolic processes. So that magnesium is required for carbohydrate, protein and fat metabolism, maintenance of normal cell membrane func-

\section{ÖZET}

Magnezyum hücre zar fonksiyonlarını, düz kas kontraksiyonlarını ve enzimatik reaksiyonları etkileyerek pek çok metabolik sürece katılan fizyolojik bir kalsiyum kanal blokörüdür. Magnezyumun Endothelin-1 (ET-1) ve Nitrik Oksit (NO) yolakları vasıtasıyla endotel fonksiyonlarını modifiye ederek dokulara kan akımında artışa neden olduğu gösterilmiştir. Magnezyum aynı zamanda N-metil-D-aspartat (NMDA) reseptör ilişkili kalsiyum içe akımını bloke ederek ve glutamat serbestleşmesini önleyerek nöroprotektif rol oynamakta ve hücreleri oksidatif stres ve apoptoza karşı korumaktadır. Hem kan akımında artışa neden olması hem de nöroprotektif etkileri magnezyumu glokom çalışmaları için iyi bir hedef molekül yapmaktadır. Magnezyumun retinada oksidatif stresi ve apoptozu azalttığı ve ganglion koruyucu etkileri olduğu gösterilmiştir. Bir takım çalışmalarda aynı zamanda magnezyumun diabetik hastalarda insulin resistansını azalttığı, glisemik kontrolü kolaylaştırdığı ve retinopatiyi önlediği gösterilmiştir. Magnezyumun lensteki iyon dengesinin sağlanmasında kritik önemi belirlenmiştir. Magnezyum eksikliğinin lentiküler oksidatif stresi arttırdığı ve iyon dengesini bozarak katarakt oluşumuna neden olduğu gösterilmiştir.

Anahtar kelimeler: Magnezyum, kalsiyum kanal blokajı, glokom, nöroproteksiyon, diabetik retinopati, katarakt

tion, synthesis of nucleic acid, and maintenance of energy metabolism [1-3].

Magnesium is a nature's calcium blocker [4,5]. In addition to direct action on calcium blockage of vascular smooth muscle, magnesium affects endothelial functions which have an impact on vascular tone and blood flow regulation. Magnesium reduces vascular tone and increases blood flow by modulating production of vasoactive agents such as endothelin-1 (ET-1) and nitric oxide (NO) and respon-

${ }^{1}$ Department of Ophthalmology, Düzce State Hospital, Düzce, Turkey

${ }^{2}$ Department of Ophthalmology, Tavas State Hospital, Denizli, Turkey

${ }^{3}$ Department of Ophthalmology, Çanakkale Onsekiz Mart University, Çanakkale, Turkey

${ }^{4}$ Department of Ophthalmology, Medeniyet University, Istanbul, Turkey

Correspondence: Şafak Korkmaz,

Düzce State Hospital, Department of Ophthalmology 81020, Düzce, Turkey Email: skorkmaz012@gmail.com

Received: 02.02.2013, Accepted: 25.03.2013

Copyright @ JCEI / Journal of Clinical and Experimental Investigations 2013, All rights reserved 
siveness to these agents [6]. Elevated magnesium levels prevents ET- 1 induced contractile responses by inhibition of ET-1's production and its hypertrophic effect $[7,8]$. Endothelium-dependent vasodilation mediated by $\mathrm{NO}$ is induced with magnesium by modifying formation and release of NO [9-11]. Indeed, magnesium therapy may improve endothelial function in patients with diabetes and coronary artery diseases $[12,13]$. Magnesium tends to increase blood flow, and decreases vascular resistance in various vascular beds $[6,9,12,14]$. Hence magnesium has been shown to inhibit vasospasm in subarachnoid hemorrhages [15] and also induces vasodilation in pre-eclampsia clinically [16].

Magnesium has gained attention as an accepted neuroprotective agent. Glutamate is the major excitatory neurotransmitter in the vertebrate central nervous system. Excessive exposure with by glutamate may destroy neuronal tissue, through $\mathrm{N}$-methyl-D-aspartate (NMDA)-mediated excitotoxicity $[17,18]$. Glutamate induces accumulation of excessive intraneuronal calcium via overactivation of NMDA receptors, and thus leads to apoptotic cell death as a result of increased production of intracellular reactive oxygen species $[19,20]$. Glutamate excitotoxicity is thought to be involved in the duration times of various number of neuronal diseases including ischemic and traumatic brain injury, Alzheimer and Parkinson's disease, and glaucoma by changing their form from acute to chronic $[21,22]$. Magnesium may prevent glutamate induced neurotoxicity by blocking NMDA receptor related calcium influx and by inhibiting the release of glutamate, hence magnesium protect the cell against oxidative stress and apoptosis [23-25]. Indeed, other potential neuroprotective mechanism attributed for magnesium is considered to be increasing blood flow dependent of vasodilator effect on calcium channel blockade $[15,26,27]$.

\section{Necessity in terms of eye tissue development}

Very little is known about ocular diseases related to magnesium deprivation in clinical practice. A number of experimental animal studies have shown that magnesium has a vital role in development and function of eye. Magnesium deficiency has been correlated with multifocal necrosis in retinal pigment epithelium as well as photoreceptor outer segment deformation and pyknotic-apoptotic changes in photoreceptor cell nuclei, probably as a result of magnesium and calcium distribution imbalance in retinal tissue [28]. Magnesium may protect the cells against the effects of glutamate, peroxynitrite, oxygen radicals and the other pathways of calcium related excitotoxicity. Magnesium influences superoxide dismutase activity in retinal tissue [29]. Magnesium is required for enzyme activity and membran integrity in retinal tissue as well as all human tissues. Magnesium is involved in all kinase reactions. It means that almost all enzymatic reactions that involve adenosine triphosphate (ATP) definitely require magnesium. Both disturbed metabolism and antioxidation pathway may contribute to magnesium deficiency induced retinal damage. Hypomagnesemia has been associated with pigmentary retinal degenerations like Kearns-Sayre syndrome and retinitis pigmentosa [30,31]. Interestingly, visual field progression has been stabilized after magnesium replacement in retinitis pigmentosa [31]. Magnesium also exists at high concentrations in retinal photoreceptors and has some physiologic activity on vision [32-34]. Caddell proposed a hypothesis that magnesium deficiency may be one of causative factors for the pathogenesis of retinopathy of prematurity as well as high arterial oxygen pressure, because magnesium deficiency results in impairment of both vasodilatator activity and protection from oxidative injury [35]. Magnesium deprivation during developmental phase may cause myelination disorders and multifocal necrosis in optic nerve [36]. Magnesium also may be necessary for maintenance of corneal surface health which is important for protection from infections and dryness. Cornea has showed some structural changes if magnesium is missing in the developmental cycle, including decreased microvilli in the epithelial cells, nuclear changes like apoptosis in the epithelial and endothelial cells through abnormal ATP activity and abnormal ion transport [37].

\section{Putative therapeutic effect in glaucoma}

Glaucoma is characterized by progressive retinal ganglion cell loss with a complex pathogenesis. Intraocular pressure (IOP) is considered the main risk factor of glaucoma, and IOP lowering therapies plays essential role in glaucoma progression control. However, glaucomatous damage may proceed progressively despite keeping IOP at the level of low teens [38], and also there is a concept of normal tension glaucoma (NTG) with IOP that is consistently at or below $21 \mathrm{mmHg}$, as known. Accordingly, the factors other than IOP may contribute to pathogenetic mechanism at least sensitizing the ganglion cell for IOP-induced damage. Vascular dysregulation deserves attention for this issue. Vascular dysregulation is caused by imbalance between vasoconstriction and vasodilatation at microcirculatory level. Vascular dysregulation induces perfusion instability, and then leads to isch- 
emia, reperfusion injury and oxidative stress. Local disturbed autoregulation in ocular tissues is thought to be as a part of primary vascular dysregulation syndrome which is caused by general dysfunction of endothelium and autonomic nervous system as seen in whole body [39-42]. Vascular tone is regulated locally by endothelium derived vasoactive agents such as ET-1 and NO. A number of studies have demonstrated the increased plasma ET-1 levels in glaucoma patients, which could contribute to glaucoma pathogenesis particularly in NTG [43-45]. Indeed, increased ET-1 level was associated with glaucoma progression despite normal IOP level [46]. ET-1 induces contraction of retinal and optic nerve head vessels, which is dependent on an influx of extracellular calcium through voltage-gated calcium channels, and then resulting in decreased ocular blood flow and ischemia [47-52]. Efficacy of ET-1 can be inhibited by calcium channel blockade. So that calcium channel blockers were evaluated for the management of glaucoma. In this sense, some calcium channel blockers have shown a positive effect on ocular blood flow and visual field in NTG $[50,53,54]$. But many systemic side effects such as hypotension, bradycardia, conduction disturbances and decrease in cardiac output can be seen during the calcium channel blocker intake, resulting in a restriction in the use for chronic diseases such as NTG [55].

Magnesium acts as a natural physiologic calcium antagonist with minimal side effects. Magnesium-induced favorable vascular effects have been demonstrated in many organ systems and previously discussed $[12,13,26]$. Therefore, these could explain how magnesium may have potential therapeutic effect in some diseases associated with perfusion abnormality via local microcirculatory disturbances and decreased blood flow such as NTG. Gaspar et al. [56] evaluated the effect of oral magnesium therapy in 10 glaucoma patients (6 with open angle glaucoma and 4 with NTG with normal or drug normalized IOP). All patients had a cold-induced digital vasospasm. $121.5 \mathrm{mg}$ of magnesium was given twice daily for 1 month and video-nailfold-capillaroscopy was used to evaluate peripheral capillary blood flow. At the end of 4 weeks of treatment, both peripheral blood flow and visual field were improved, as the former was statistically significant and the latter not. They concluded that magnesium seemed to have a beneficial effect on the visual field in glaucoma patients [56]. Similarly, Aydın et al. [57] investigated the efficacy of oral magnesium supplementation on visual field perimetry indices and ocular blood flow in pure NTG by a prospective controlled randomized clinical trial. Fifteen NTG patients were received $300 \mathrm{mg}$ oral magnesium for 1 month and blood flow velocity of orbital vessels such as ophthalmic, posterior ciliary and central retinal arteries were measured by color Doppler imaging. After 1 month of magnesium therapy, the improvement in visual field mean deviation and pattern standard deviation were found statistically significant in the study group compared with control group. They did not report any significant change in ocular blood flow parameters provided by color Doppler imaging. Authors speculated that other mechanisms than increased blood flow could be responsible for the improvement in the visual field [57].

The known facts about impact of magnesium on the ocular blood flow are limited. Elevated extracellular concentrations of magnesium inhibit ET1-induced contraction in porcine ciliary arteries. However, complete inhibition was achieved only with very high concentrations of magnesium, sufficient to provoke cardiac arrest [58]. Magnesium influences vascular tonus in dose-dependent manner via calcium antagonistic effect non-competitively. It was shown that non-toxic lower dose could be quite enough for visual improvement in NTG, higher concentrations may not be needed. The $300 \mathrm{mg} /$ day oral magnesium intake may have an effect on more distal vasculature (particularly the capillaries) which cannot be revealed by color Doppler analysis [57]. More likely, the perfusion anomaly caused by vascular dysregulation at microcirculatory level is regulated by magnesium without the need of increased blood flow of orbital vessels, in a mechanism which possibly related to calcium antagonistic effect. This impact can be explained by regulation of endothelial function by magnesium. Magnesium therapy may also improve endothelial function [12,13]. In addition to reverse interaction with ET-1, magnesium induces endothelium-dependent vasodilation mediated by endothelial NO $[9,10]$. NO, derived from nitric oxide synthase-3 in vascular endothelium, contributes to regulation of local circulatory disturbances, and may be neuroprotective by causing vasodilation and increased blood flow in the glaucoma patients $[59,60]$.

Repeated reperfusion injury which occurs as a result of perfusion instability via vascular dysregulation induces glutamate retention in retinal tissue. Glutamate is the principal excitatory neurotransmitter in retina as discussed before [61]. Elevated glutamate has been demonstrated in vitreous of glaucoma patients [21]. Exposure to chronic low dose glutamate could damage retinal ganglion cells [18]. 
Glutamate induced excitotoxicity is predominantly managed by NMDA subtype of glutamate receptor.

Overstimulation of NMDA receptors leads to excessive calcium influx through NMDA receptors and voltage-gated calcium channels, and then a number of enzymes become inappropriately activated to promote apoptotic cell death [19]. Calcium influx into retinal ganglion cells through NMDA receptors seems to have major value in producing permanent damage, and may be a critical step that can be interfered. NMDA receptor antagonists such as memantine and MK-801 and dihydropyridine derived calcium channel antagonists have been shown to attenuate NMDA related neurotoxicity in retinal ganglion cells $[17,18,62]$. As a physiological calcium channel blocker, magnesium may be a good alternative in terms of neuroprotection of retinal ganglion cells with minimal side effects. Magnesium ions proceed to regulate conductance of the NMDA channels by blocking the pores in a voltage dependent manner, and to limit neuronal calcium influx [63]. Elevated magnesium levels can also inhibit influx of calcium non-competitively at NMDA receptors $[64,65]$. Calcium mediated neurotoxicity depends on the activation of distinct signaling pathways resulting in free radical generation, which is also triggered by NMDA receptor. Magnesium deficiency may promote oxidative injury. Magnesium can prevent retinal ganglion cells from oxidative injury by combined effects on NMDA receptor activity, glutathione synthesis and lipid peroxidation $[66,67]$. Magnesium also influences superoxide dismutase activity in retinal tissue [19]. Magnesium is required for glutathione biosynthesis and its depletion has been associated with decreased antioxidant properties $[68,69]$. Oxidative stress is involved in glaucoma pathogenesis [70]. Overproduction of NO by neuronal and inducible NO synthesis acts as neurodestructive agent because of the production of peroxynitrites [59]. Reduced oxidative load intervened by magnesium may also contribute to attenuate progression of glaucoma.

In conclusion, some evidence supports that magnesium can prevent the loss of neuron in glaucoma via an undefined mechanism. Only two studies have shown meritorious effect of magnesium on visual fields clinically. Further studies are required to confirm these findings, and to reveal the underlying pathways.

\section{Association of diabetic retinopathy}

Clinical and experimental evidences suggest that magnesium may reduce the risk of diabetic retinopathy in patients with diabetes. Magnesium may play an important role in the maintenance of glucose metabolism and insulin homeostasis. Dietary magnesium intake and serum magnesium level have been inversely correlated with fasting serum insulin level and positively correlated with markers of insulin sensitivity [71,72]. A graded inverse relationship between serum magnesium level and incidence of type 2 diabetes has been shown prospectively by the Atherosclerosis Risk in Communities Study, and low serum magnesium levels were found to be an independent predictive factor for the incidence of diabetes [73]. Further studies tended to confirm similar association so that plasma magnesium concentration in diabetic patients is lower than non-diabetic patients [74-77]. The mechanisms of how magnesium could affect insulin resistance or reduce diabetic complications like diabetic retinopathy are not defined yet. Magnesium acts as a natural calcium antagonist [4]. Elevated cytosolic free calcium concentration causes the deficiency of insulin actions on glucose uptake, and leads to worsen hyperglycemia $[78,79]$. Magnesium may regulate insulin actions through interfering the effect of calcium. Otherwise many enzymes of carbohydrate metabolism require magnesium as a cofactor [80]. Low intracellular magnesium concentrations result in a defective tyrosine-kinase activity and alter insulin sensitivity by disrupting signaling pathway interaction at receptorial or postreceptorial phase [81-84]. It is also likely that magnesium can improve insulin actions through altering directly enzyme function involving in glucose matabolism. Hyperglycemia may get worse because of low magnesium-induced insulin resistance. All these evidences suggest that magnesium may have effect on pathogenesis and treatment of diabetic retinopathy. Plasma magnesium concentration of diabetic patients with retinopathy has been shown to tend to be lower when compared with diabetic patients without retinopathy $[76,77,85-$ 87]. Hypomagnesemia has also been linked to the most severe degree of retinopathy $[76,85,87]$. One prospective study demonstrated an inverse relationship between plasma magnesium level and both development and progression of diabetic retinopathy at the end of long term follow up. A similar relationship remained unchanged after adjusting for the potential confounding effects of hemoglobinA1c and disease duration [87]. In contrast to these observations, some studies have not found similar association, and supported that there was no consistent association between serum level of magnesium and diabetic retinopathy [88-90]. Lastly, conflicting reports can be seen on this issue. In terms of development and progression of diabetic retinopathy, the fact that whether serum magnesium is only an 
indicator or a causative factor has not been yet understood. Although magnesium probably plays a role to break down insulin resistance in peripheral target tissues, to what extent this influence might be effective for preventing retinopathy is a matter of debate. Magnesium may be protector against diabetic retinopathy, but it is clear that further evaluation is needed to reveal true etiologic association between magnesium and diabetic retinopathy if there is.

\section{Magnesium: Have a role in cataractogenesis?}

Magnesium, a common cation that plays an important role as a cofactor for numerous enzymes, is closely linked with calcium, sodium and potassium homeostasis. The integrity of lens both structurally and functionally largely depends on the maintenance of intracellular and extracellular ionic homeostasis. Magnesium is found to be critically important in maintaining normal ionic homeostasis of lens. Two main enzymes, sodium potassium adenosine triphosphatase ( $\mathrm{Na}+\mathrm{K}+$ ATPase) and calcium adenosine triphosphatase (Ca2+ ATPase), which seem very important to lens active ion transport mechanism use magnesium as a cofactor and are largely magnesium dependent [91].

Role of magnesium in the onset and progression of cataract has been evaluated by various researchers. It was found that the ionic imbalance in age related cataract is mainly associated with decreased magnesium and potassium and increased calcium and sodium [92]. Also magnesium supplementation has been shown to have a preventive role in Shumiya cataract rats [93]. It is clearly indicated that magnesium deficiency is correlated with high calcium levels in the lens. Probably the oxidative stress resulting from magnesium deficiency play a role to increase lens calcium concentration and finally result in cataractogenesis [94]. Magnesium deficiency has been shown to cause increased oxidative stress and trigger cataractogenesis by increasing inducible NO synthase (iNOS) expression and NO release. Pretreatment of rats with NO synthase inhibitors has been shown to prevent onset of selenite-induced cataract and reduce lens calcium content [95]. Culture of human lens epithelial cells in magnesium deficient medium shows 6 fold increase in expression of INOS as compared to those cultured in medium with normal magnesium concentration. Also treatment of culture medium with INOS inhibitors attenuate increased release of NO [96]. In another study it was shown that treatment with magnesium taurate also delays the onset and progression of cataract in galactose fed rats. This effect was attributed to the restorage of the lens calcium/ magnesium ratio and the reduction of the lenticular oxidative stress [97].

Magnesium deficiency causes increased lenticular oxidative stress, alterations in function of ATPases resulting in ionic imbalances consist of reduced intracellular potassium and increased calcium and sodium levels. Increased sodium causes cellular swelling and increased calcium causes convertion of soluble proteins into insoluble ones. All these changes finally result in cataractogenesis. Although current literature provides evidence for the association of magnesium deficiency with cataract, its role can be thought as an associated factor with several other factors.

\section{CONCLUSION}

Magnesium is of critical importance in regulating intracellular enzymatic functions including those of ocular tissue. The role of magnesium in several ocular diseases has been studied widely. The association of magnesium levels with ocular pathologies such as glaucoma, diabetic retinopathy and cataract may primarily attributed to its highly important role as a cofactor for membrane associated ATPases, vessel smooth muscle modulating effects and also role in oxidative stress regulation mechanisms. The review of current literature supports the need of further investigations to evaluate the role of magnesium as a supportive approach in various ocular diseases.

\section{REFERENCES}

1. Wester PO. Magnesium. Am J Clin Nutr 1987;45:13051312.

2. Saris NEL, Mervaala E, Karppanen H. Magnesium; An update on physiological, clinical and analytical aspects. Clin Chim Acta 2000;294:1-26.

3. Cowan JA. The biological chemistry of magnesium, 1st edn. New York: Wiley-VCH, 1995:5-7.

4. Iseri LT, French JH. Magnesium: nature's physiologic calcium blocker. Am Heart J 1984;108:188-193.

5. Levine BS, Coburn JW. Magnesium, the mimic antagonist of calcium. N Engl J Med 1984;310:1253-1255.

6. Touyz RM. Role of magnesium in the pathogenesis of hypertension. Molecular Aspects of Medicine 2003;24:107-136.

7. Laurant $P$, Berthelot $A$. Endothelin-1-induced contraction in isolated aortae from normotensive and DOCAsalt hypertensive rats: effect of magnesium. $\mathrm{Br} \mathrm{J}$ Pharmacol 1996;119:1367-1374.

8. Berthon N, Laurant P, Hayoz D, et al. Magnesium supplementation and deoxycorticosterone acetate--salt hypertension: effect on arterial mechanical properties and on activity of endothelin-1. Can J Physiol Pharm 2002;80:553-561. 
9. Haenni A, Johansson K, Lind L, Lithell H. Magnesium infusion improves endothelium-dependent vasodilation in the human forearm. Am J Hypertens 2002;15:10-15.

10. Yang ZW, Gebrewold A, Nowakowski M, et al. Mg(2+)induced endothelium-dependent relaxation of blood vessels and blood pressure lowering: role of NO. Am J Physiol Regul Integr Comp Physiol 2000;278:628639.

11. Szabo C, Farago M, Dora E. Effect of small changes in extracellular magnesium concentration on the tone of feline mesenteric arteries: involvement of endothelium. Acta Physiol Hung 1992;79:295-303.

12. Barbagallo M, Dominquez LJ, Galioto A, et al. Oral magnesium supplementation improves vascular function in elderly diabetic patients. Magnesium Research 2010;23:131-137.

13. Shechter $M$, Sharir $M$, Labrador $M J$, et al. Oral magnesium therapy improves endothelial function in patients with coronary artery disease. Circulation 2000;102:2353-2358.

14. Teragawa $\mathrm{H}$, Kato $\mathrm{M}$, Yamagata $\mathrm{T}$, et al. Magnesium causes nitric oxide independent coronary artery vasodilation in humans. Heart. 2001;86:212-216.

15. Pyne GJ, Cadoux-Hudson TA, Clark JF. Magnesium protection against in vitro cerebral vasospasm after subarachnoid haemorrhage. $\mathrm{Br} \mathrm{J}$ Neurosurg 2001;15:409-415.

16. Shear R, Leduc L, Rey E, Moutquin JM. Hypertension in pregnancy. New recommendations for management. Curr Hypert Reports 1999;1:529-539.

17. Chaudhary P, Ahmed F, Sharma SC. MK801-a neuroprotectant in rat hypertensive eyes. Brain Res 1998;792:154-158.

18. Vorwerk CK, Lipton SA, Zurakowski D, et al. Chronic low dose glutamate is toxic to retinal ganglion cells: toxicity blocked by memantine. Invest Ophthalmol Vis Sci 1996;37:1618-1624.

19. Sucher NJ, Lipton SA, Dreyer EB. Molecular basis of glutamate toxicity in retinal ganglion cells. Vision Res 1997;37:3483-3493.

20. Arundine M, Tymianski M. Molecular mechanisms of glutamate-dependent neurodegeneration in ischemia and traumatic brain injury. Cell Mol Life Sci 2004;61:657-668.

21. Dreyer EB, Zurakowski D, Schumer RA, Podos SM, Lipton SA. Elevated glutamate levels in the vitreous body of humans and monkeys with glaucoma. Arch. Ophthalmol 1996;114:299-305.

22. Coyle JT, Puttfarcken P. Oxidative stress, glutamate, and neurodegenerative disorders. Science. 1993;262:689-695.

23. Gathwala G. Neuronal protection with magnesium. Indian J Pediatr 2001;68:417-419.

24. Hoffman DJ, Marro PJ, McGowan JE, Mishra OP, Delivoria-Papadopoulos M. Protective effect of $\mathrm{Mg} \mathrm{SO} 4$ infusion on NMDA receptor binding characteristics during cerebral cortical hypoxia in the newborn piglet. Brain Res 1994;644:144-149.

25. Ustun ME, Duman A, Ogun CO, et al. Effects of nimodipine and magnesium sulfate on endogenous antioxidant levels in brain tissue after experimental head trauma. J Neurosurg Anesthesiol 2001;13:227-232.

26. Veyna RS, Seyfried D, Burke DG, et al. Magnesium sulfate therapy after aneurysmal subarachnoid hemorrhage. J Neurosurg 2002;96:510-514.

27. Altura BT, Memon ZI, Zhang A, et al. Low levels of serum ionized magnesium are found in patients early after stroke which result in rapid elevation in cytosolic free calcium and spasm in cerebral vascular muscle cells. Neurosci Lett 1997;230:37-40.

28. Gong H, Amemiya T, Takaya K. Retinal changes in magnesium deficient rats. Exp Eye Res 2001;72:2332.

29. Szabo ME, Droy LM, Doly M, Braquet P. Ischaemiaand reperfusion-induced $\mathrm{Na}^{+}, \mathrm{K}^{+}, \mathrm{Ca}^{2+}$ and $\mathrm{Mg}^{2+}$ shifts in rat retina: effects of two free radical scavengers, SOD and EGB 761. Exp Eye Res 1992;55;39-45.

30. Katsanos KH, Elisaf M, Bairaktari E, Tsianos EV. Severe hypomagnesemia and hypoparathyroidism in Kearns-Sayre syndrome. Am J Nephrol 2001;21:150153.

31. Liang SY, Lee LR. Retinitis pigmentosa associated with hypomagnesaemia. Clin Experiment Ophthalmol 2010;38:645-647.

32. Somlyo AP, Walz B. Elemental distribution in Rana pipiens retinal rods: quantitative electron probe analysis. J Psychol 1985;358:183-195.

33. Dizhoor AM, Olshevskaya EV, Peshenko IV. Mg2+/ $\mathrm{Ca} 2+$ cation binding cycle of guanylyl cyclase activating proteins (GCAPs): role in regulation of photoreceptor guanylyl cyclase. Mol Cell Biochem 2010;334:117124.

34. Peshenko IV, Dizhoor AM. Guanylyl cyclase-activating proteins (GCAPs) are $\mathrm{Ca}^{2+} / \mathrm{Mg}^{2+}$ sensors: implications for photoreceptor guanylyl cyclase (RetGC) regulation in mammalian photoreceptors. J Biol Chem 2004;279:16903-16906.

35. Caddell JL. Hypothesis: The possible role of magnesium and copper deficiency in retinopathy of prematurity. Magnes Res 1995;8:261-270.

36. Gong H, Takayi K, Amemiya T. Ultrastructure of the optic nerve in magnesium-deficient rats. Ophthalmic Res 2003;35:84-92.

37. Gong H, Takami Y, Takaya K, Amemiya T. Corneal changes in magnesium-deficient rats. Cornea 2003;22:448-456.

38. Parc CE, Johnson DH, Oliver JE, et al. The long-term outcome of glaucoma filtration surgery. Am J Ophthalmol 2001;132:27-35.

39. Flammer J, Orgül S, Costa VP, et al. The impact of ocular blood flow in glaucoma. Prog Retin Eye Res 2002;21:359-393. 
40. Grieshaber MC, Mozaffarieh M, Flammer J. What is the link between vascular dysregulation and glaucoma? Surv Ophthalmol 2007;52:S144-S154.

41. Flammer J, Haefliger IO, Orgül S, Resink T. Vascular dysregulation: a principal risk factor for glaucomatous damage? J Glaucoma 1999;8:212-219.

42. Flammer J, Pache M, Resink T. Vasospasm, its role in the pathogenesis of diseases with particular reference to the eye. Prog Retin Eye Res 2001;20:319-349.

43. Kaiser HJ, Flammer J, Wenk M, Lüscher T. Endothelin-1 plasma levels in normal-tension glaucoma: abnormal response to postural changes. Graefes Arch Clin Exp Ophthalmol 1995;233:484-488.

44. Sugiyama T, Moriya S, Oku H, Azuma I. Association of endothelin-1 with normal tension glaucoma: clinical and fundamental studies. Surv Ophthalmol 1995;39:49-56.

45. Yorio T, Krishnamoorthy R, Prasanna G. Endothelin: is it a contributor to glaucoma pathophysiology? J Glaucoma 2002;11:259-270.

46. Emre M, Orgul S, Haufschild T, et al. Increased plasma endothelin-1 levels in patients with progressive open angle glaucoma. Br J Ophthalmol 2005;89:60-63.

47. Rubanyi GM, Polokoff MA. Endothelins: molecular biology, biochemistry, pharmacology, physiology, and pathophysiology. Pharmacol Rev 1994;46:325-415.

48. Orgül S, Cioffi GA, Wilson DJ, et al. An endothelin-1 induced model of optic nerve ischemia in the rabbit. Invest ophthalmol Vis Sci 1996;37:1860-1869.

49. Meyer P, Lang MG, Flammer J, Lüscher TF. Effects of calcium channel blockers on the response to endothelin-1, bradykinin and sodium nitroprusside in porcine ciliary arteries. Exp Eye Res. 1995;60:505-510.

50. Toriu N, Sasaoka M, Shimazawa M, et al. Effects of lomerizine, a novel $\mathrm{Ca} 2+$ channel blocker, on the normal and endothelin-1-disturbed circulation in the optic nerve head of rabbits. J Ocul Pharmacol Ther 2001;17:131-149.

51. Ciulla TA, Pawlyk BS, Harris A, et al. Endothelin-1-mediated retinal artery vasospasm and the rabbit electroretinogram. J Ocul Pharmacol Ther 2000;16:393-398.

52. Nyborg NC, Prieto D, Benedito S, Nielsen PJ. Endothelin-1-induced contraction of bovine retinal small arteries is reversible and abolished by nitrendipine. Invest Ophthalmol Vis Sci 1991;32:27-31.

53. Cellini M, Possati GL, Caramazza N, et al. The use of flunarizine in the management of low-tension glaucoma: a color Doppler study. Acta Ophthalmol Scand 1997;224:57-58

54. Boehm AG, Breidenbach KA, Pillunat LE, et al. Visual function and perfusion of the optic nerve head after application of centrally acting calcium-channel blockers. Graefes Arch Clin Exp Ophthalmol 2003;241:3438.

55. DeWitt CR, Waksman JC. Pharmacology, pathophysiology and management of calcium channel blocker and beta-blocker toxicity. Toxicol Rev 2004;23:223238.
56. Gaspar AZ, Gasser P, Flammer J. The influence of magnesium on visual field and peripheral vasospasm in glaucoma. Ophthalmologica 995;209:11-13.

57. Aydın B, Önol M, Hondur A, et al. The effect of oral magnesium therapy on visual field and ocular blood flow in normotensive glaucoma. European J Ophthalmol 2010;20:131-135

58. Dettmann ES, Luscher TF, Flammer J, Haefliger IO. Modulation of endothelin 1-induced contractions by magnesium/calcium in porcine ciliary arteries. Graefes Arch Clin Exp Ophthalmol 1998;236:47-51.

59. Neufeld AH, Hernandez MR, Gonzalez M. Nitric oxide synthase in the human glaucomatous optic nerve head. Arch Ophthalmol 1997;115:497-503.

60. Shareef S, Sawada A, Neufeld AH. Isoforms of nitric oxide synthase in the optic nerves of rat eyes with chronic moderately elevated intraocular pressure. Invest Ophthalmol Vis Sci 1999;40:2884-2891.

61. Thoreson WB, Witkovsky P. Glutamate receptors and circuits in the vertebrate retina. Prog Retin Eye Res 1999;18:765-810.

62. Sucher NJ, Lei SZ, Lipton SA. Calcium channel antagonists attenuate NMDA receptor-mediated neurotoxicity of retinal ganglion cells in culture. Brain Res 1991;551:297-302.

63. Mayer ML, Westbrook GL, Guthrie PB. Voltage-dependent block by Mg2+ of NMDA responses in spinal cord neurones. Nature 1984;309:261-263.

64. Mori H, Masaki H, Yamakura T, Mishina M. Identification by mutagenesis of a Mg2+-block site of the NMDA receptor channel. Nature 1992;358:673-675.

65. Burnashev N, Schoepfer R, Monyer H, et al. Control by asparagine residues of calcium permeability and magnesium blockade in the NMDA receptor. Science 1992;257:1415-1419.

66. Regan RF, Jasper E, Guo Y, Panter SS. The effect of magnesium on oxidative neuronal injury in vitro. $\mathrm{J}$ Neurochem 1998;70:77-85.

67. Regan RF, Guo Y. Magnesium deprivation decreases cellular reduced glutathione and causes oxidative neuronal death in murine cortical cultures. Brain Res 2001;890:177-183.

68. Mills BJ, Lindeman RD, Lang CA. Magnesium deficiency inhibits biosynthesis of blood glutathione and tumor growth in the rat. Proc Soc Exp Biol Med 1986;181:326-332.

69. Freedman AM, Mak IT, Stafford RE, et al. Erythrocytes from magnesium-deficient hamsters display an enhanced susceptibility to oxidative stress. Am J Physiol 1992;262:C1371-375.

70. Tezel G. Oxidative stress in glaucomatous neurodegeneration: mechanisms and consequences. Prog Retin Eye Res 2006;25:490-513.

71. Humphries S, Kushner H, Falkner B. Low dietary magnesium is associated with insulin resistance in a sample of young, nondiabetic Black Americans. Am J Hypertens 1999;12:747-576. 
72. Huerta GM, Roemmich JN, Kington ML, et al. Magnesium deficiency is associated with insulin resistance in obese children. Diabetes Care 2005;28:175-181.

73. Kao WH, Folsom AR, Nieto FJ, et al. Serum and dietary magnesium and the risk for type 2 diabetes mellitus: the Atherosclerosis Risk in Communities Study. Arch Intern Med 1999;159:2151-2159.

74. Sjögren A, Florén C-H, Nilsson A. Magnesium, potassium and zinc deficiency in subjects with type II diabetes mellitus. Acta Med Scand 1988;224:461-465.

75. Sjögren A, Florén C-H, Nilsson A. Magnesium deficiency in IDDM related to level of glycosylated hemoglobin. Diabetes 1986;35:459-463.

76. Hatwal A, Gujral AS, Bhatia RP, et al. Association of hypomagnesemia with diabetic retinopathy. Acta Ophthalmol (Copenh) 1989;67:714-716.

77. Sharma A, Dabla S, Agrawal RP, et al. Serum magnesium: an early predictor of course and complications of diabetes mellitus. J Indian Med Assoc 2007;105:16,18,20.

78. Draznin B. Cytosolic calcium and insulin resistance. Am J Kidney Dis1993;21(suppl):32-38.

79. Draznin B, Sussman K, Echel RH, et al. Possible role of cytosolic free $\mathrm{Ca}$ concentrations in mediating insulin resistance of obesity and hyperinsulinemia. J Clin Invest 1988;82:1848-1852.

80. Paolisso G, Scheen A, D'Onofrio F, Lefèbvre P. Magnesium and glucose homeostasis. Diabetologia 1990;33:511-514.

81. Barbagallo M, Dominguez LJ, Galioto A, et al. Role of magnesium in insulin action, diabetes and cardio-metabolic syndrome X. Mol Aspects Med 2003;24:39-52.

82. Barbagallo M, Dominguez LJ. Magnesium metabolism in type 2 diabetes mellitus, metabolic syndrome and insulin resistance. Arch Biochem Biophy 2007;458:40-47.

83. Takaya J, Higashino H, Kobayyashi Y. Intracellular magnesium and insulin resistance. Magnes Res 2004;17:126-136.

84. Suarez A, Pulido N, Casla A, Casanova B, Arrieta FJ, Rovira A. Impaired tyrosine kinase activity of muscle insulin receptors from hypomagnesaemic rats. Diabetologia 1995;38:1262-1270.

85. McNair P, Christiansen C, Madsbad S, et al. Hypomagnesemia, a risk factor in diabetic retinopathy. Diabetes 1978;27:1075-1077.
86. Ceriello A, Giugliano D, Dello Russo P, Passariello N. Hypomagnesemia in relation to diabetic retinopathy. Diabetes Care 1982;5:558-559.

87. de Valk HW, Hardus PL, van Rijn HJ, Erkelens DW. Plasma magnesium concentration and progression of retinopathy [letter]. Diabetes Care. 1999;22:864-865.

88. Lee CT, Gayton EL, Beulens JW, Flanagan DW, Adler Al. Micronutrients and diabetic retinopathy: a systematic review. Ophthalmology 2010;117:71-78.

89. Erasmus RT, Olukoga AO, Alanamu RA, Adewoye $\mathrm{HO}$, Bojuwoye B. Plasma magnesium and retinopathy in black African diabetics. Trop Geogr Med 1989;41:234-237.

90. Walter RM, Uriu-Hare JY, Olin KL, et al. Copper, zinc, manganese, and magnesium status and complications of diabetes mellitus. Diabetes Care 199;14:10501056.

91. Agarwal R, lezhitsa I, Agarwal P, Spasov A. Magnesium deficiency: does it have a role to play in cataractogenesis? Exp Eye Res 2012;101:82-89.

92. Dilsiz N, Olcucu A, Atas M. Determination of calcium, sodium, potassium and magnesium concentrations in human senile cataractous lenses. Cell Biochem Funct 2000;18:259-262.

93. Nagai N, Ito $\mathrm{Y}$, Inomata M, et al. Delay of cataract development in the Shumiya cataract rat by the administration of drinking water containing high concentration of magnesium ion. Biol Pharm Bull 2006;29:12341238.

94. Nagai N, Ito Y. Delay of cataract development in the Shumiya cataract rat by water containing enhanced concentrations of magnesium and calcium. Curr Eye Res 2007;32:439-445.

95. Ito $Y$, Nabekura T, Takeda M, et al. Nitric oxide participates in cataract development in selenite-treated rats. Curr Eye Res 2001;22:215-20.

96. Nagai N, Fukuhata T, Ito Y. Effect of magnesium deficiency on intracellular ATP levels in human lens epithelial cells. Biol Pharm Bull 2007;30:6-10.

97. Agarwal R, lezhitsa I, Awaludin NA, et al. Effects of magnesium taurate on the onset and progression of galactose-induced experimental cataract: In vivo and in vitro evaluation. Exp Eye Res 2013;18. pii: S0014-4835:00047-X. 